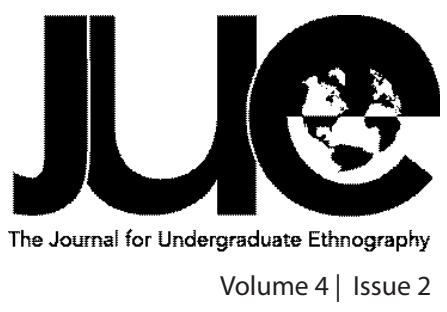

\title{
Forms of Resistance against the Government of Unemployment in Germany
}

\author{
Nora Ziegler \\ University College Maastricht, nora.ziegler@yahoo.com
}

\section{ABSTRACT}

he research question guiding this study is: What are effective forms of resistance of long-term unemployed in Germany against the government of unemployment? Following Michel Foucault, the government of unemployment is understood as the institutions, procedures, analyses, calculations and tactics forming a set of solutions to unemployment and its social and personal effects. The government of unemployment exercises power over the unemployed through the creation of individualized and politically marginalized subjectivities. The group KEAs e.V. responds to the political marginalization of the unemployed through independent self-organization. Furthermore, they challenge the individualized subjectivities imposed by the government of unemployment by fostering solidarity and practicing "agonal" resistance collectively and individually. This study is based on qualitative research conducted with the KEAs in the form of semi-structured in-depth interviews and participant observation.

Keywords: Unemployment, Governmentality, Resistance, Solidarity 


\section{INTRODUCTION}

"Critique should be an instrument for those who fight, those who resist and refuse what is. Its use should be in processes of conflict and confrontation"-Foucault 1980, 236

In the summer of 2004 a mass protest wave swept through Germany in response to the implementation of the neoliberal Hartz workfare reforms, commonly referred to as "Hartz IV" in Germany. Hartz IV is the fourth of the Hartz laws combining the former unemployment benefits with welfare benefits. Long-term unemployment benefits are generally referred to in Germany as "Hartz IV", which has also come to stand for the entire Hartz reform. Once the mass mobilized protests faded, individuals and groups of long-term unemployed moved on to more direct forms of action. The KEAs e.V. is one such group that formed in response to the Hartz laws and the abandonment of their cause by larger political organizations and unions. KEA stands for Kölner Erwerbslose in Aktion (Cologne's Unemployed in Action) and Kölner Erwerbslosen Anzeiger (Cologne Unemployed Gazette), the newspaper published and distributed by the group. The KEAs are an independent organization with the aim of articulating and representing the interests of the group members based on their personal experience of oppression as a result of their unemployed status. The three main activities of the group are the production and distribution of their newspaper and other information material, weekly open legal advice and support, and the organization and support of creative protest. Furthermore, the group constitutes a platform for mutual support, where individual members can exchange experiences, accompany each other to the government agencies and pool their time and resources based on principles of solidarity.

The aim of my research was to investigate forms of resistance of long-term unemployed in Germany. I developed this specific research interest out of a broader concern with the exercise of power and forms of resistance in modern societies and particularly in my native country Germany. In contrast to the vast theoretical literature, I perceived a lack of academic interest in the localized forms of resistance as understood and practiced by economically and socially marginalized groups. Antonio Gramsci has argued that the conflict between the hegemonic power and the groups it represses can inspire alternative imaginations for building counter-hegemonic ideas and practices. Living in a society thriving on pretensions of social cohesion, I was

\section{"Critique should be an instrument for those who fight, those who resist and refuse what is. Its use should be in processes of conflict and confrontation" - Foucault 1980, 236}

moved to seek out the very material conflicts fought out on the margins of our society and explore the practical problems and implications of political resistance in Germany as a democratic neo-liberal market society.

\section{METHODS}

After finding their homepage www.die-keas.org on the web I contacted the KEAs and was invited to one of their weekly open meetings. I encountered a group of quite diverse and friendly people sitting around a large table with one computer in a comfortable informal atmosphere. I joined in the meeting which involved a discussion of personal issues, reports from the legal advice service, the planning of upcoming activities and finally my request to conduct ethnographic research with members of the group. After discussing my idea and some of the group's doubts and reservations, my proposal was accepted and we agreed upon the general focus of my research.

My research consists of five semi-structured in-depth interviews of 60 to 120 minutes along with participant observation of two open group meetings and one of the legal advice and support sessions offered by the group for Hartz IV recipients. I conducted the interviews in German and transcribed, coded and analyzed the data in its original language. I later translated some of the interview material and the most important codes and key concepts for use in this report. All names of interview participants have been anonymized and three of the participants are referred to by their existing pseudonyms as used in their own publications.

Some of the interview participants volunteered after I pro- 
posed the project in our first meeting but the final sample was also influenced by the participant's availability during my visits to Cologne. The five interview participants are all German, male and do not originate from Cologne. This reflects the general composition of the group quite well since only a few of the active members of the group are female, non-German or locals from Cologne. However, for this reason the lack of a female, local or non-German voice in this study also presents a significant limitation. Intuitively, the composition of the group may reflect on how its activities correspond to the needs of particular groups in German society. It would be the object of a further study to investigate how forms of resistance differ in their relevance for different positions in society.

The research question guiding this study is: What are effective forms of resistance of long-term unemployed in Germany against the government of unemployment? I answer this question in three sections. The first section deals with the government of unemployment and how it is experienced by the participants. I develop an understanding of practices of self-formation creating the unemployed subjectivity as individualized and politically marginalized. In the second section I explore how the KEAs formed as an independent organization within the political and social landscape of Cologne. Finally, in the third section I examine two main forms of resistance in the activities of the KEAs: fostering solidarity and "throwing sand in the wheels". I conclude by weaving these themes with reviewed literature into a detailed account of effective forms of resistance against the government of unemployment.

\section{THE GOVERNMENT OF UNEMPLOYMENT}

All of the five participants emphasized that they are resisting Hartz IV and the structures it entails. The Hartz reforms include the reduction of welfare benefits, the increase of requirements and conditions imposed on welfare recipients and the re-individualization of social risk (Butterwegge 2010). They form part of a shift from social welfare to workfare after the model of traditional "workfare states" such as Britain, the United States and Australia. The central element of these workfare regimes is the transferral of the social and economic risks of unemployment from the state to the individual who is expected to take responsibility for their own welfare and therefore has specific obligations towards the government and community in return for assistance
(Mcdonald and Marston 2005, 375).

Drawing on the approach of Michel Foucault, workfare regimes such as the Hartz reforms are understood as part of a set of solutions to unemployment and its social and personal effects as a "problem of government" (ibid. 378). This set of solutions is here referred to as the "government of unemployment". The term "government" goes beyond manifestations of political ideology and policy making, encompassing "the ensemble formed by the institutions, procedures, analyses and reflection, the calculations and tactics that allow the exercise of this very specific albeit complex form of power, which has as its target population" (Foucault 1991, 142). "Population" is an entity made available by particular knowledges and technologies such as statistics and scientific discourse (Dean 1995, 569). The purpose of government is "the welfare of the population, the improvement of its condition, the increase of its wealth, longevity, health etc." (Foucault 1991, 140). The population is therefore at once the subject of needs and the object of governmental power. The government of unemployment manifests in rationalities and discourses on the macro-level as well as interactions on the micro-level of social practice. For example, on the macro-level it includes discourses of deserving and undeserving unemployed developed in the mass media. For example, the German boulevard paper BILD regularly produces images and stories of welfare recipients as lazy and undeserving with headlines such as "The dirty tricks of welfare scroungers... and we have to pay" or "Hart IV cheats - Luxury life in Tenerife". These discourses construct and make available a population of 'undeserving unemployed' as the target of government (Ingram and Schneider 2005). On the micro-level, it for instance involves the relationship between the unemployed client and the case manager through which the rights and obligations between the state and the individual are articulated (Mcdonald and Marston 2005).

The interview participants experience Hartz IV as a political instrument directed against them as long-term unemployed but also at the precariously employed and others potentially or indirectly affected by the workfare measures. Frank explained:

With Hartz IV...Yeah there my basis for subsistence is threatened. And that's also what's intended right? Of course, I always tell myself this jokingly um or cynically, I don't know, if the point of Hartz IV is to force me to lift my behind then they've accomplished that, of course. 
The Hartz reforms are not experienced as a political failure but as a functioning mechanism targeted at them as long-term unemployed with the aim of activating them and adjusting their behavior. Furthermore, they are experienced as a "frontal assault" on them as individuals, their dignity and means of subsistence.

The government of unemployment is directed at the conduct of individuals (Dean 1995, 561). It entails practices of selfformation that shape the attributes, capacities, orientations and the moral conduct of clients to the job centers (ibid. 567). For example, training measures not only target the client's skills and capacities but also their attitudes and expectations. Furthermore, these practices are designed to engage clients in self-government, meaning the internalization of the standards, goals and norms entailed in the Hartz reforms. The government of unemployment is therefore not imposed and enforced only from above but involves the complicity of the individual who accepts the values embodied in the system and invests in the power relations of which they are part (Cole 2007, 136). The aim of practices of self-formation is the improvement and "remoralization" of the unemployed whose habits, tastes and values are perceived as requiring "disciplinary and morally coercive techniques" in order to bring them into line with generally accepted behaviors and attitudes (Valverde 1996, 361). The government of unemployment is therefore based on a notion of what constitutes acceptable values and choices, and not working is not a valid choice (ibid. 364).

The shift from welfare to workfare can be described as a reorganization of political rationalities in response to changing technologies of government (Rose 2010, 200). In contrast to welfare regimes centered on the individual as dependent subject, workfare reforms are situated within a specific morality of the "active subject" as active, innovative, flexible and entrepreneurial. The active subject is the autonomous individual with individual skills and capacities standing in competition with other individuals, in need of life-long improvement and self-formation (Spilker 2010). Furthermore, the active subject is willing to take responsibility for its own welfare, motivated to engage in self-government and has realistic, meaning low expectations concerning its future (Mcdonald and Marston 2005). Unemployment as economic dependency and self-caused due to lack of flexibility or initiative is thus morally deviant and not an acceptable form of being.

The active subject is the ethical self to which the individual should aspire and practices of self-formation are the process by which this is achieved. The government of unemployment therefore creates its object by constructing a specific unemployed subjectivity. Unemployment is more than an economic status, involving a social identity constructed through general discourse and in every day interactions (Mcdonald and Marston 2005). Specifically in Germany the "Hartz IV recipient" has become the unemployed subjectivity as the object of the government of unemployment (Heiter 2008). In Germany it is common for someone receiving Hartz IV to be labeled as "Hartz IV", or "Hartz IV-ler". This subjectification is achieved through a variety of techniques, discourses and practices.

First, the Hartz IV subjectivity is imposed through the construction of a socio-cultural minimum subsistence-level (Heiter $2008,66)$. The level of welfare benefits constitutes the minimum living standards considered acceptable for the Hartz IV-recipient. Since these standards are far below average German livings standards, they contribute to the stigmatization and social exclusion of Hartz IV recipients (Butterwegge 2010). As Uwe recalls:

I used to be very socially isolated because often it's like this that you can't afford to go out anymore right? Going to a pub or something that's just not possible anymore right?

Furthermore, the Hartz IV subjectivity is produced through disentitlement and discipline (Heiter 2008, 67). The relationship of Hartz IV recipients with the job centre is a situation of powerlessness and lack of individual autonomy. For example, Hansi talked about the "Eingliederungsvereinbarung", a contract signed by clients to the job centre and their case manager:

In the end, the agency basically puts its demands in there. If I don't sign the thing it comes as an administrative act. Thereby it becomes a valid contract even without my consent. And if I do not comply with the "agreed" terms... um...I get sanctioned and they can withhold my benefits completely. Ultimately with a $100 \%$ sanction they can even withhold rental costs, so ultimately they threaten you with hunger and homelessness if you don't do exactly what the agency demands

The individual agency and integrity of the client is completely undermined through the one-sided nature of these agreements. Whereas the client must comply with the job centre's demands, the measures and trainings offered by the agency are discretionary clauses and therefore do not constitute actual 
rights and obligations (Voigtländer 2012). The resulting disentitlement and the threat to their means of subsistence, forms the basis for coercion.

According to Christoph Butterwegge (2010), with Hartz IV, Germany's social government has adopted a workfare policy with coercion as its central element. For example, clients of the job centre can be forced to participate in work measures such as the "one euro job", a measure designed to help re-integrate the long-term unemployed into the regular labor market. However, measures that can actually fulfill this purpose are scarce and are granted at the discretion of the agency (Voigtländer 2012). Furthermore, these measures are situated mainly in the service sector which is dominated by unstable employment relationships and low compensation. Therefore, these measures generally do not achieve integration into the labor market but social exclusion and function as a disciplinary measure (Trube 2004). Upon the question why he opposes these "one euro jobs", Frank replied that:

In the majority they don't contribute to placing people in employment and um that's why it's nonsense and...but it's an instrument that makes people docile so they'll take any crap job in order to earn a little bit more

The power differential and use of coercion in the relationship between the unemployed client and the job centre emphasizes the obligations of the individual to the state and society while undermining their basic rights and individual agency. This disentitlement contributes to the individualization of unemployment, meaning that the individual is constructed as responsible for the risks and consequences of unemployment (Voigtländer 2012). In the following, Mati explains how he perceives this individualization:

There's this basic assumption that the Hartz IV-ler is at fault. So you're the bad guy, you're the rogue, you're the one cashing money and expensive trainings and all this stuff from us.

This individualization of unemployment, treating unemployment as self-caused, creates divides among the unemployed undermining the unemployed individual's capacity of social and political action (Voigtländer 2012). Frank expressed this in the following:

I think Hartz IV contributes heavily to the reduction of solidarity in society...right? That's what it's about. That's what it aims at. Even among the unemployed there's classes right? [...] There's also those who take part in measures for zero Euros, he looks better than the one who gets the same money but doesn't do anything for it

Since the responsibility for unemployment is attached to the individual, the unemployed are divided into deserving and nondeserving, a system which undermines solidarity and results in a form of divide and rule. The value system of deserving and undeserving unemployed is socially constructed and reproduced by unemployed individuals trying to prove their deservedness and by deflecting the image of the undeserving onto others (Ingram and Schneider 2005, Howe 1998).

Finally, the Hartz IV subjectivity involves anxiety connected to the perceived threat to their basic means of existence and to the coercion and disentitlement experienced through Hartz IV. Fear was an important topic in the interviews. Dealing with the job centre and the constant threat to one's livelihood as well as feelings of isolation and being left alone were sources of fear:

I knew at some point they would have put me down to zero, I wouldn't have received any more money as punishment, or I would have had to accept a damn one euro job, and that frightened me, yeah. [Frank]

Somehow I never felt alright if I had a personal appointment at the agency the next day. I would have problems sleeping because you always have this sword of Damocles hanging over your head because these benefit cuts are always hanging in the air. [Uwe]

The fear and anxiety connected to unemployment further undermine the individual's capacity of political action. On the one hand, unemployed individuals are intimidated and weakened in their relation to the job centre (Voigtländer 2012). On the other hand, in combination with an increase in precarious work conditions throughout Germany, the individualization of the risks of unemployment through Hartz IV creates general anxiety among Germany's poor (Spilker 2010). Fear of unemployment and Hartz IV has a dividing influence between working and non-working poor, increasing the stigmatization and social isolation of the unemployed.

The lack of means for collective action of the unemployed is exacerbated by their political marginalization. The unemployed cannot be adequately represented through conventional political 
mechanisms because their interests are opposed to the dominant interests in society. The interests of economic growth dominate the political sphere in modern democracies and therefore these political systems tend to marginalize those who cannot be integrated into the economic system through gainful employment and consumption (Duarte 2007). Therefore, alternative approaches to the labor market questioning the exclusive focus on gainful-employment such as the basic income or disposable time models cannot find genuine representation through conventional political mechanisms (Blaschke 2003, Roth 2010). The long-term unemployed are neglected as a social group with specific needs and interests because unemployment is considered as deviant and defect. Economic participation is a condition for social citizenship and belonging, meaning that the unemployed are excluded from political participation while simultaneously being included as potential workers (Mcdonald and Marston 2005). Unemployment is thus accompanied by the experience of not being represented by mainstream political institutions (Rein 1997). Many of the participants voiced this feeling of being excluded from Germany's political landscape. For example, Mati stated the following:

Um if you look at the political landscape it's like this, there are four parties in Germany that all say the same things right? Um so then where's the pluralism in this? It doesn't exist. [...] or then I'd have to vote extreme that means the left or the right, I don't have any other choice [Mati]

Furthermore, many forms of political representation are closely tied to economic participation and thereby exclude those who are not gainfully employed. For example, labor unions represent the unemployed on the basis of their potential re-entry into the labor market but cannot represent the long-term unemployed as a group situated outside the economic system. Therefore, participants experience that when such institutions do create spaces for the representation of the unemployed, in practice these tend to work against the long-term interests of the unemployed and therefore obscure their political exclusion:

The point is we discovered pretty quickly that the trade unions are programmatically inadequate for the unemployed. They're simply not responsible for us as in they don't do anything for us. [...] They have more like an alibi function: 'we have an unemployment committee' but it doesn't do anything [Frank]
In summary, the Hartz reforms as part of the government of unemployment engage the unemployed individual in self-formation and self-government by means of a specific Hartz IV subjectivity as the "active subject" responsible for its own welfare and the risks of unemployment. The social isolation, stigmatization, disentitlement and discipline of unemployed subjects contribute to the imposition and internalization of an individualized unemployed subjectivity. Furthermore, the political marginalization of the unemployed within German institutions silences the voices of those who become politically active despite economic and social constraints. In the following sections I analyze how resistance is possible despite these constraining factors.

\section{RESISTANCE THROUGH SELF-ORGANIZATION}

In response to the marginalization of the political interests of the long-term unemployed, the KEAs are a self-organized group based on self-representation and independence from religious, political and state institutions. This self-organization is described by Hansi in the following:

Not to be dependent on any higher institutions, be it the state, parties, churches, whatever um you're personally concerned (betroffen) and yeah everyone can contribute with what he thinks and feels

Interviewer: And if you want to be independent, does this also cause difficulties?

Um yes well it all has advantages and disadvantages so decision-making processes sometimes take a bit longer here then it sometimes also takes longer to actually put some activity into practice um but in return it's not given from above but yeah we discuss things at eye level [...]. Well I definitely believe this to be much more advantageous than being dependent on parties or other institutions...also external funding, if we applied for external funding, we would directly get demands for how to work from the sponsor. Since we now sometimes deliberately breach rules and take the risk of being barred from the job centers, I think all that wouldn't be so easy anymore.

A main advantage of being self-organized and independent is that members can represent their own interests without interference through external demands and obligations. This also allows the creation of more open and flexible structures meaning that each individual contribution and experience is of greater con- 
sequence to the overall outcomes. Therefore, self-organization allows those who are personally afflicted by poverty and unemployment to improve their individual situation and to take part in collective political action (Blaschke 2003).

The political dissidence of the unemployed is often hidden and incoherent and its effectiveness also largely depends on its unpredictability. An example of this is the protest activities of the KEAs which, as Hansi explains above, involve deliberate transgressions and confrontations with state institutions. Therefore, the forms of resistance of the unemployed are difficult to integrate into more rigid political or social structures (Rein 1997). Besides independence of religious and political institutions, the KEAs do not cooperate with the job centre and work measures such as the "one euro job". In contrast to such mandatory work measures, self-organized groups like the KEAs foster voluntary involvement, openness and independence (Trube 2004).

Hansi also reflects on a key problem with self-organization concerning mobilization and the implementation of ideas. Effective collective protest depends on mobilizing structures usually provided by institutions such as political parties and trade unions. Mobilizing structures include action repertoires, networks and organizational forms that promote communication, coordination and commitment between potential actors (Lahusen 2012 , 4). However, the KEAs have been successful in creating their own structures and acquiring experience in political work over time. In this section I show how the KEAs have dealt with these problems and succeeded in establishing and sustaining an independent self-organized unemployment organization. First I describe the influence of their specific location in Cologne and then discuss the roles of individual connections and selfrepresentation based on personal experience (Betroffenheit) in successful self-organization.

The specific location in which a group develops has great influence on their organizational forms and strategies. Participants agreed that Cologne displays a familial atmosphere in which those who are politically active all know each other. For example, Paul was personally acquainted with most of the KEA members long before he joined the group. However, for Frank this entails substantial difficulties:

Especially those who come from a background where they were already socialized politically um they all know each other and all hedge ten year old grudges against each other and feed on their bad experiences. So that really surprised me here that you can't just start at zero but instead they say we need to do it like this, we need a charter, we need rules of procedure...

Cologne's familial situation means that potential actors are already connected but are also often impeded by their shared backgrounds and histories. Furthermore, this shared background means that many actors in the unemployment movement or leftist scene are used to a certain type of procedure centered on official functions and formal procedures. According to Frank, these "affectations" are counterproductive because they shift the focus of the organization to its own structures and procedures, neglecting the actual content and activities. The absence of these structures and functions in the KEAs shifts their focus to content and allows members to build an "intimate base", to get to know each other outside of the political.

An outstanding characteristic of the KEAs is thus their focus on activism and putting ideas into practice through concrete actions. Activities of the KEAs include the weekly sessions in which legal advice and support are offered, and regular visits to and protests at job centers and other state institutions in Cologne. For example, KEA members enter the job centre with flags and banners, distribute information material, establishing contact with other Hartz IV recipients but also seeking confrontation with the management and staff.

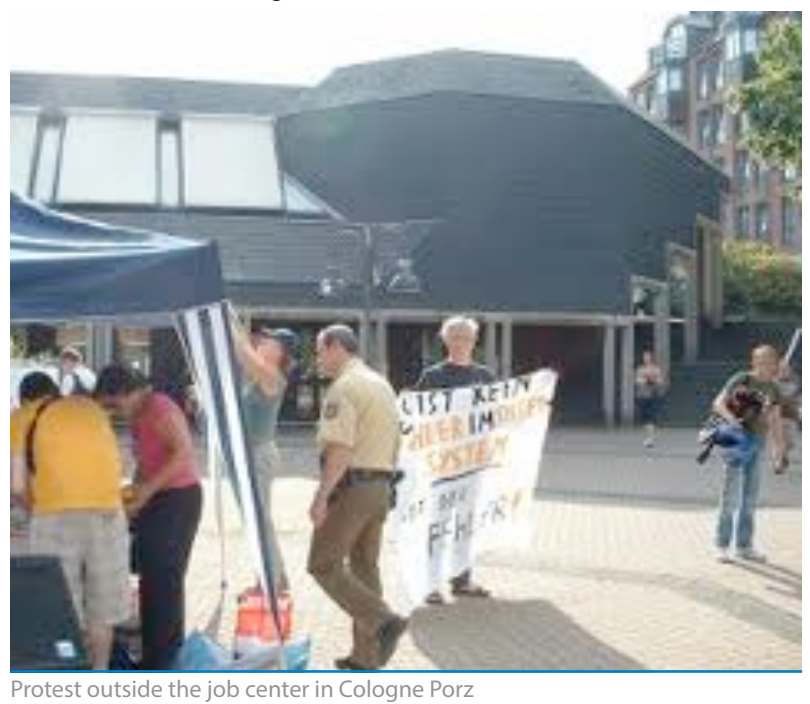




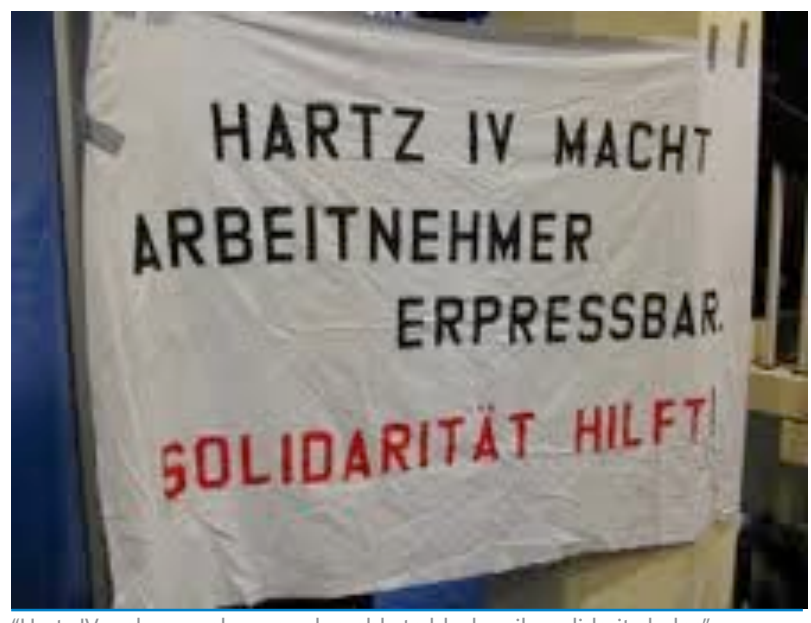

"Hartz IV makes employees vulnerable to blackmail - solidarity helps"

A second important characteristic is the "intimate base" described by Frank, created through informal organizational structures. The KEAs have a board fulfilling the legal organizational requirements but in practice there is no hierarchy and there are no permanent functions or positions. In the two meetings in which I took part as participant observer, there was no chair person leading the discussion. Each time the meeting followed an agenda beginning with personal issues where each member could bring their personal problems or ideas into discussion. For example, a woman asked advice for responding to the job centre's demand for a service charge statement she didn't have. Other KEA members took time to offer advice and support. This was followed by reports from the legal advice sessions and past activities and the planning of upcoming events. Decisions were unanimous and made openly in the plenum.

The familial context in Cologne therefore presents obstacles which the KEAs overcome by fostering intimacy and consciously avoiding rigid official structures. However, this familial situation in Cologne also facilitates communication and coordination between different potential actors and therefore allows access to mobilizing structures without relying on higher political and social institutions. Individual informal connections are key means of mobilization and cooperation and these are provided by the political community in Cologne. For example, Frank became involved in the Cologne unemployment movement through personal contacts made over the internet:

Well it's individual people. Specifically in the internet I met one guy with whom I communicated. We're meeting there and there come along. And there I met two others who then had the idea with the Board of the Unemployed

Individual connections are important because they are based on personal solidarity rather than shared interests and positions. Such bonds of personal solidarity are stronger and more reliable than more formal political alliances. Furthermore, the KEAs rely on individual allies in order to remain flexible and independent. Official organizational alliances compromise the independence of the KEAs and require more or less fixed interests and positions. Again, Frank made a clear point in this respect:

We're more interested in personal allies. I'm not interested in Attac as an ally, then I'd have to negotiate with Attac or something. Instead I'm interested in the Attac members who due to a particular solidarity embrace the cause and don't care whether their flag is involved or something and that works surprisingly well in Cologne

These individual alliances foster productive and flexible cooperation between different groups and initiatives. According to Hansi, the KEAs have active contact with many different groups with whom they share experiences and sometimes coordinate their activities. The KEAs establish contact to others who are affected by Hartz IV through their newspaper and protest activities in the job centers as well as the open legal advice and support sessions:

We usually go at the beginning of the month because that's when it's the busiest, we go to the waiting area in the job centre, talk to the people, introduce ourselves a little and just give them some information material and ideally if we have it the new newspaper [Hansi]

The importance of individual connections and establishing personal contact to others affected by Hartz IV is linked to the idea of self-representation. Rather than representing interests, for instance the interests of long-term unemployed, the KEAs seek to represent their own needs as individuals based on personal experience. Frank and Uwe both expressed this:

We never do it in the name of 'the unemployed' [...] we want to be an example of 'we for us". And anyone who wants can join and define themselves as part of the 'us', anyone is free to do that but we are no representative organization working for the interests of others, we don't want to be that. [Frank] 
For us it's about self-organization, self-representation, we also don't have the pretension of speaking for all unemployed, we speak for ourselves. [Uwe]

Paul expressed a similar view by describing the KEAs as his union, through which he can primarily work for his concrete personal needs rather than following ideological or more abstract political objectives:

I think it's good that people first of all organize themselves according to their personal needs and thereby develop this consciousness: who is your friend and who is your enemy? Why is the situation the way it is? [...] So I believe that the economy or the social context of the people should form the starting point

Self-representation is based on personal experience of oppression which fuels the political activism of those affected and targeted by the government of unemployment. This personal experience is the source of the political activism of the KEAs and strongly shapes their content and activities. For example, their newspaper, which can be downloaded on www.die-keas.org/ kea, includes many personal experiences and strong opinions inspired by these. Furthermore, this personal experience generates a militancy that strengthens their activism and makes it unpredictable. Frank suggested that this is because the activists experience Hartz IV as a personal assault on them individually and therefore strongly feel that they are morally in the right.

The KEAs therefore provide a platform through which personally affected individuals can organize and engage in collective action but always based on their own personal experience. Since self-representation is based on personal experience rather than common objectives and goals, there should be substantial internal difference and disagreement within the KEAs. According to Hansi the KEAs are a "colorful mix" with people from different backgrounds and opinions and Uwe describes the KEAs as a "heterogeneous bunch" with many different political backgrounds. On the other hand, Paul conceded that the KEAs are in fact not as diverse as they seem. Most already have a background of political activism and share broader political views. For example, the group includes a group of male Iranian immigrants with a background of left-wing activism. Yet, even though many of the people who come to the KEAs for legal advice are women and people with Russian, Turkish or other non-German backgrounds, few of these become active members with the KEAs.
This suggests that the KEAs are not completely open as an organization but seems to appeal to a certain type of people. The extent to which this relates to the activities of the KEAs is discussed in the final section of this article.

In view of the organizational form of the KEAs, a relevant factor is the informal and grassroots structure of the KEAs. Frank explains that many people who joined the KEAs but then moved on to other organizations did so because they sought a more official function within the organizational structure. The structure of the KEAs appeals particularly to activists from an anarchist or leftist background, which applies to four of the five interview participants. The political spectrum of the KEAs is thus limited in some ways but nevertheless accommodates a wide range of backgrounds and opinions. Paul explained that the KEAs manage to accommodate a wide range of people because they achieve a balance between two main forms of participation:

They have a more open conception so that people can participate who aren't anarchist or leftists...and they still manage not to completely lose, let's say, this anarchist part because that would be the second danger to become a mere self-help group or service thing. [...] this balance between self-help, self-organization and a radical political claim, they do that quite well [...]. I find it impressive what they do on Wednesdays this legal advice and support um and Frank doesn't really take part in that or Hansi so in a way that's two wings of the organization but they get on well with one another [...] and I would say that's the strength of the organization, that this balance is possible and constantly being renewed

The KEAs are structured in a way that allows people to contribute in different ways and cooperate despite disagreements or different political views. Intersections through their shared experience of unemployment hold the group together. There is a common understanding that people have a shared experience of being targeted and oppressed through Hartz IV and the government of unemployment. Hansi stated that:

of course there's common intersections and overlaps, that we don't approve of the job centre, I think we all agree there and for now we don't really need more than that. The rest you can discuss now and then but the important thing is that we agree here: the job centre has to go

Besides these intersections, what binds the individual members 
of the KEAs together is a common identity and self-confidence gained and constructed in a number of ways. First, Frank explains that the activities of the KEAs are reproduced through the internet and the feedback and appreciation encountered here strengthen the organization:

It makes you strong, you feel the solidarity, you feel the feedback and, you feel that somewhere a signal has been perceived and a spark has been ignited let's say

Therefore, Frank identifies the moment in which the KEAs first began to claim their activities as decisive in their development. While in the beginning they would report their activities anonymously in the third person, a point came where individual members began to write on the homepage and in the newspaper about the activities of the KEAs as a group, and thereby the KEAs began to take credit and responsibility for their actions. This self-awareness as a group is strengthened by a certain self-image constructed through their activities and self-presentations. For example, the logo of the KEAs is the kea parrot indigenous to New Zealand, a bird which lives and cooperates in large flocks:

I It's about the kea in allusion to this, well the flock and principle of solidarity of the parrots and I thinks it's funny [...] it also has the charm of Robin Hood or something. [Frank]

Furthermore, Hansi talked about a protest at the job centre where all participants wore blue wigs because he as the obvious activist with blue hair had been singled out and punished as the main culprit in a previous protest event:

At the last event the others put on blue wigs in order to increase the level of difficulty: Call the police and collect the blue-haired.

Small jokes and ideas like this increase the collective self-awareness of the KEAs and contribute to binding them together despite their differences and disagreements.

In conclusion to this section, the following can be said about the successful self-organization of the KEAs within Cologne's political community. Being independent from higher political or social structures requires the establishment of personal informal connections based on genuine solidarity. This solidarity originates in an overlap of personal experiences of the government of unemployment as well as other fine intersections. These intersections bind together individuals who each fight for their own personal needs resulting in radical political activism.
Furthermore, the construction of a collective self-image binds together the group and promotes solidarity among the KEAs.

\section{SOLIDARITY AND SAND IN THE WHEELS}

I have argued that the government of unemployment imposes an individualized and politically marginalized subjectivity on the unemployed and other welfare recipients. Furthermore, I demonstrated how self-organization of the unemployed based on self-representation and individual connections constitutes one form of resistance to their political marginalization. In the following section I analyze how the activities of the KEAs fostering solidarity and "throwing sand in the wheels" form acts of resistance against the subjectivities imposed through practices of self-formation of the government of unemployment.

One form of resistance carried out by the KEAs consists of fostering solidarity within and outside the group. The notion of solidarity carried by the KEAs involves helping others by helping oneself in collective resistance as well as the security of mutual support contained in the image of the flock. Hansi and Uwe expressed this notion very clearly:

We help each other, we experience solidarity. It's this helping each other and resisting together against this oppression. Um I think this is generally lacking in society, this helping each other. [Hansi]

It's this feeling of being helpless of being at the mercy of the institutions that you don't have any more when you're being accompanied, when you fight back, when you do something yourself. [Uwe]

On the one hand, KEA members become active in order to help themselves and find ways of coping with the circumstances of unemployment. However, as Frank explains, through collective organization individuals can help each other through self-help:

I always say that what the individual KEA achieves for himself, he achieves for all by opening up that path for others and the rights that he fights for. And what we achieve for others by accompanying them or whatever, we each achieve for ourselves. That's a pleasant reciprocal effect.

This works in a number of ways. First, individual KEA members bring together different conceptual and material resources in a way that benefits all and supports their individual struggles. Most importantly, they share legal expertise and accompany each other as well as non-members to the job centers and le- 
gal institutions. Every Wednesday the KEAs offer an open session where anyone can come and seek legal advice and support. When I visited a session around six legal 'experts' from the KEAs were sitting around a table at one end of the room, each talking to one advisee while more were lining up in an improvised wait- ing area at the other end of the room. The following banner was hanging from the wall and several copies of the KEA newspaper and other information material was lying around for people to read while waiting:

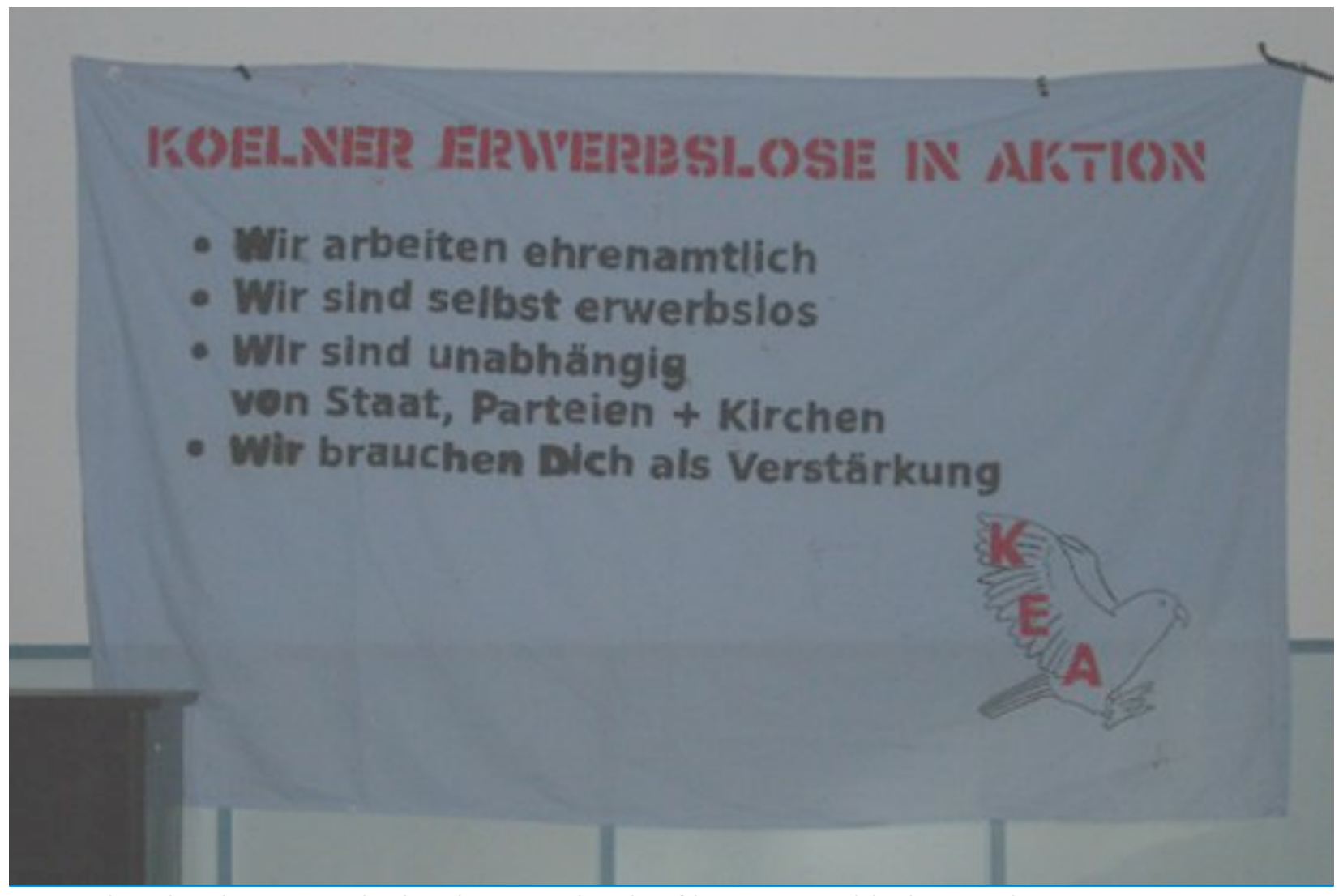

"We are working voluntarily; we are unemployed ourselves; we are independent of the state, parties and churches; we need your support" 
Through these legal advice sessions, KEA members share their legal expertise and experience and offer support for the struggles of others.

Furthermore, Frank suggested that besides the struggles and protest, the KEAs try to create a better life for themselves, through mutual material support but also by creating a social space and community feeling among the members:

Self-organization is necessarily also, next to the grimness of our fight, about being able to breathe and live a better life together right? This is a part of solidarity and we decided that we also need these moments of relaxation for ourselves...

Besides protest and direct resistance against state institutions, the KEAs therefore also create an alternative way of living and being for themselves. For example, the participants stressed that the KEAs provided social contacts and a community in times when they felt isolated and alone due to their unemployment:

With the KEAs I regained the feeling of being needed. So it was also very good for my self-esteem. [Uwe]

Then I was completely in open loop and I was just...I would say under-socialized and it was just good to have people um human contacts...yeah so pretty simple I really hit rock bottom last year and I really had to tell myself, I need to socialize now. What should I do? Well ok it was actually quite logical, go to the KEAs that will help, they're nice people and there's something happening there and so on. That was really good...That really helped me. [Paul]

Furthermore, the KEAs create a sense of community to counteract the anxieties and fear experienced by individual members. The image of the flock of parrots that support each other and work together for their mutual benefit is an important aspect here. Frank explained that the feeling of belonging to a close group gives him confidence and security in dealing with the state institutions:

To know that I'm not alone, I can go to the job centre as part of a flock. That completely takes away my fear. And um when it started, when Hartz IV came, I was really scared shitless

As explained above, dealing with the job centre involves a perceived threat to the means of existence of the participants. This threat is based on the power differential between the agency and the client as well as the immediate threat of sanctions. According to Uwe, the presence of just one witness already alleviates the situation significantly and gives the client greater leverage with the job centre. He also explained that knowledge of the group's support gives each individual greater confidence and autonomy in relation to the job centre:

We don't leave anyone behind [...] for me that's lived solidarity. Or for example with Hansi, who is now being supported in his cause. You know, his complete refusal to cooperate (Totalverweigerung). From being supported with groceries to other things right? I mean Hansi doesn't have to worry even if he's kicked out of his apartment. Here in this house he'll at least have a bed. I mean he'll never end up under a bridge you know, for me that's lived solidarity.

The group solidarity of the KEAs therefore enables the individual coping and resistance strategies of its members. Individual strategies of resistance of unemployed vary and are often diffuse and hidden (Rein 1997). However, whether individuals choose to accept Hartz IV and confidently claim their rights or refuse to cooperate choosing to fight back, the collective solidarity fostered within the KEAs supports and connects their individual struggles in a way that benefits all. Fostering solidarity among the unemployed is thus a form of collective and individual empowerment enabling people in their individual forms of resistance against the government of unemployment.

Besides fostering solidarity within the group, the KEAs try to carry this solidarity outside and encourage solidarity among other unemployed as well as in society as a whole. This involves showing others in a similar situation the benefits of being in a group and of helping each other. For example, Uwe suggested that:

We quasi exemplify it outwards through the way we live and others maybe realize that solidarity is worth it because we achieve tangible results. [...] it's enough if they organize themselves in their neighborhoods, if one neighbor accompanies the other (to the job centre). If both receive unemployment benefits and accompany each other.

Furthermore, it involves reducing people's anxiety and showing that unemployment is not as threatening as it is made out to be in public opinion. Fear of unemployment exerts pressure on the working poor to accept precarious working conditions and low wages (Spilker 2010). By creating networks of solidarity, the KEAs try to reduce the vulnerability of the precariously 
employed population and give people confidence to resist despite the threats embodied in Hartz IV. This was particularly the position of Paul who believes that people need to realize that resistance is empowering rather than an additional vulnerability:

The message should be that when you are with us then you'll get through this, then we'll make it work....and we also support you, that could be the next step, with your struggles in the work place and even if you become unemployed you won't fall into a void

This solidarity with and support of the working poor is actively shown through protest activities such as the "one euro job walks" (Eineurojob Spaziergänge) where the KEAs visit organizations employing one euro jobbers, confront the employers and offer support and solidarity to the employees.

However, the support and community offered by the KEAs may not be of equal relevance to the majority of unemployed or other welfare recipients in Germany. As stated in the introduction, most of the KEA members are male, above middle age and not originally from Cologne. It is quite likely that many groups in society have access to other networks and sources of community and support and therefore are not affected by unemployment in the same way as the participants of this study. For example, many women, young adults, locals and members of ethnic minority communities may have access to family resources closed to other groups but also face more restrictions to their political activities. This would be the object of further research into forms of resistance against the government of unemployment.

As indicated by Paul in the quote above, solidarity is not limited to the unemployed but includes the working population and also transcends national boundaries. Frank explained that everyone is affected by workfare measures, not only those who are currently unemployed and directly affected:

Everyone is affected even if they don't receive unemployment benefits but everyone who is now employed is potentially affected by Hartz IV so it would be reasonable for them to fight it. Also to save their job and their salary right? Therefore, the KEAs see it as their task to show solidarity towards other groups. For example, Frank talked about the strikes in children's day care centers in Cologne, which they supported in solidarity and fought to abolish one euro jobs in these centers. Here the cause of the unemployed is directly linked to that of the day care centre employees whose jobs and wage level is threat- ened by the competition created through Hartz IV work measures. Furthermore, Paul argued that the unemployed and the working poor are divided through the discourse of undeserving unemployed and widespread fear of unemployment and Hartz IV. He suggested ways of increasing contact to and solidarity between these groups:

Creating personal contacts to and supporting working people in different areas that you encounter when you look around, I mean that will take place somehow. I mean there are always unemployed people coming into the open legal advice and of course these unemployed people worked before and know people who work and might soon be working again themselves... I mean only a minority is unemployed the whole time. And if you use these contacts to get into these jobs and these neighborhoods something could definitely take shape...

The individual personal connections elaborated in the preceding section can thus be used to promote solidarity among the poor, working and non-working, and thereby counteract the dividing influence of the government of unemployment, specifically through the individualization of the risks of unemployment and discourses labeling the unemployed as undeserving (Howe 1998).

Spreading solidarity is a means for the unemployed to compensate for their loss of social and political rights and empower themselves as a group and in their individual relations with the job centre (Voigtländer 2012). Increased solidarity and the mutual support of the group allow unemployed individuals to create empowered subjectivities in opposition to the individualized and disentitled subjectivity imposed through the government of unemployment. Effective resistance against the government of unemployment necessitates a refusal of the types of individuality imposed through practices of self-formation and the promotion of alternative forms of subjectivity (Thompson 2003). Fostering solidarity recreates the unemployed subjectivity as socially embedded and challenges the notion of unemployment as selfcaused underlying the individualization of unemployment. Furthermore, the new subjectivities created through solidarity are self-confident and aware of their rights, as opposed to the fear, disentitlement and vulnerability inscribed in the Hartz IV subjectivity.

Many of the activities of the KEAs are thus geared towards 
encouraging solidarity and enabling people's individual forms of coping and resistance against the government of unemployment. The interview participants characterized their own protest and resistance as "throwing sand in the wheels". This means that their protest is subversive and deliberately seeks to disturb and disrupt the bureaucratic mechanisms of the government of unemployment. Their resistance can therefore be characterized as "agonal", as opposed to "cooperative", meaning that given power structures are rejected and undermined (Heiter 2008, 70). For example, by refusing to sign a contract with his case manager or accepting any of the job centre's requirements and measures, Hansi is withdrawing himself from the power relations of the job centre rather than investing in them. He thereby refuses the complicity and internalization by means of which the government of unemployment can take effect in people's lives. Agonal resistance therefore also involves rejecting the value system embodied in Hartz IV. For example, KEA members question and seek to deconstruct the stigmatized image of the long-term unemployed:

There is a conception of humanity (Menschenbild) behind this, a normative concept (Werteverständnis), and I want to contribute to revealing that it is a bad conception Frank On the other hand, acts of cooperation involve individual empowerment in relation to the job centre but do not challenge the power relations it embodies. For example, Uwe also makes use of the legal support offered by the KEAs to procure attractive training measures from the job centre. Such acts are instances of individual empowerment but do not qualify as agonal resistance.

Furthermore, "throwing sand in the wheels" suggests a diffuse and bottom-up form of resistance constituting the sum of many different individual acts. Often these acts are hidden or unintentional but in their sum they can significantly destabilize existing power relations (Pickett 1996). Within the activities of the KEAs "throwing sand in the wheels" is practiced on the collective level through protest and encouraged on the individual level in the form of legal dispute.

As an example of disruptive and subversive protest, Frank talked about the first big "Zahltag" in 2007, a mass organized event in Cologne where on the first working day of the month protesters including the KEAs went to the job centers for protests lasting several days:

And in the first days it came to a police escalation where the police were beating and the manager or someone was screaming and gesticulating wildly "this is going too far, we both didn't want this", so he meant us and him whereupon one of us said, I don't remember exactly, "why, why do you think that we didn't want this?" These are the images we need right?

In Frank's view the aim of protest is to provoke conflict, cross lines and thereby publicly problematize Hartz IV and the job centers as well as causing bureaucratic costs. The protests organized and carried out by the KEAs are deliberately unpredictable and militant. Rather than building on mass organized demonstrations, the KEAs have their own more discrete channels of mobilization based on the individual connections described in the preceding section which gives them an important advantage of unpredictability:

We have our own mobilization lists where we contact people, then and then we have an event planned, come join, if not then not, so that the job centre can't prepare for us so that we have this surprise effect, so they don't roll out the red carpet and take extra care not to do anything wrong but when we're gone it's the same as ever: cheating people, blackmail, coercion... [Uwe]

There's definitely a militant momentum in these acts of disobedience. When the job centre says you're allowed to do this, you have a right to protest but please do it outside we say no. No. Our house is the job centre, here we have our cause and our cause is our personal experience and no one has the right to tell us please stay outside. [Frank]

The militancy and unpredictability of protest emphasizes the political and subversive intentions of the KEAs.

On the individual level the KEAs offer support and encouragement empowering individuals to practice their own coping and resistance strategies. On the one hand the primary aim is to ensure the well-being of each individual:

Well our main goal must be that all involved, as in all members...um...pull through, get their money, stabilize or improve their living conditions...attacking one is attacking all...and then to support others and contribute to the improvement of conditions for all unemployed [Paul]

However, an overall aim is also to encourage people to "fight back", exert pressure on the job centers and practice agonal individual resistance. On the one hand this can involve complete refusal to cooperate as in Hansi's case or other more subtle acts 
such as legal and bureaucratic confrontations. For example, in one of the meetings I attended Hansi informed the others that he had accompanied a friend who had been sanctioned with $30 \%$ for failing to hand in responses to his mandatory job applications. Hansi and his friend went to the job centre to dispute the sanction since most employers do not respond to applications. The case manager was unfriendly and seemed inadequately informed about the legal rights of the client until Hansi threatened to register an official complaint. Such acts resist the disentitlement and discipline of the unemployed client in their relationship with the job centre.

"Throwing sand in the wheels" is a celebration of struggle detached from overarching theory or ideology (Pickett 1996). According to Pickett, ideological or theoretical critique is necessarily top-down and does not create the conditions necessary for autonomous local resistance. The KEAs provide the resources and opportunities for people to become individually active but do not prescribe higher objectives or theoretical principles. Instead, they emphasize the individual personal experience motivating each individual to engage in resistance. In this sense, "throwing sand in the wheels" can be understood as tactical rather than strategic resistance. Tactical resistance of the individual emerges in conditions of powerlessness and aims to opportunistically change the situation in the individual's favor (Philipps 2008). For example, someone who follows the advice of the KEAs and legally appeals a sanction does so to improve their own personal circumstances. Here the motivation is not to overthrow the power relation in which the individual is situated. Nevertheless, such acts constitute forms of resistance because the individual refuses to engage in self-government and fights back rather than internalizing the compliant and intimidated Hartz IV subjectivity. "Throwing sand in the wheels" as a celebration of struggle therefore interrupts the practices of self-formation through which the unemployed are governed.

However, in many cases unemployed individuals make use of the support provided by the KEAs in order to solve an outstanding problem but are not further committed to political activism or other forms of resistance. For example, a woman I met at one of the legal advice sessions told me she was just seeking help with understanding and filling out forms, saying "I can handle my business on my own". Furthermore, the professionalism and legal competency of the KEAs is in danger of be- ing misunderstood as a service or charity. Therefore, individual empowerment does not always lead to agonal resistance:

Of course when we accompany someone to the agency then we also deescalate...like we don't go there to punch some case manager in the face [...] when people go there alone, it does happen that people lose it and then there's someone who can mediate a little for both sides and who first of all wants to make things easier for the unemployed but somehow also for the agency when there's a very difficult case at hand [Hansi]

Therefore, the advice and help offered by the KEAs can have cooperative effects because conflicts and problems are solved that would otherwise escalate and increase the frustration and militancy of the unemployed but also show up the conflicts embodied in Hartz IV and the job centers. However, this is a necessary contradiction because the first priority of the KEAs is to ensure the well-being of its members and those for whom they provide legal advice and support. According to Voigtländer, when unemployment initiatives cooperate with state institutions this occurs out of a position of marginalization because there are in that moment no available alternatives (Voigtländer 2012).

\section{CONCLUSION}

The KEAs can be understood as an activist organization in resistance against the government of unemployment. The government of unemployment constitutes techniques, mechanisms, agencies and discourses involved in the management of unemployment. The government of unemployment exercises power over the actually and potentially unemployed by imposing the subjectivity of the "Hartz IV-ler". This subjectivity is based on the individualization of unemployment, its risks and effects and therefore involves anxiety, guilt and pressure to perform. Furthermore, this subjectivity divides and disciplines the unemployed, reducing their capacity for political action. Since the interests of the long-term unemployed stand in direct opposition to the dominant economic interests of society, they can also not rely on support by larger institutions such as political parties and trade unions. Therefore, Germany's unemployed find themselves in a position of political marginalization.

The KEAs as a self-organized self-representing group face many difficulties in terms of resources and mobilization structures but in return are able to develop agonal forms of resistance 
challenging the very foundations of the government of unemployment. This study has identified two major forms of resistance practiced in the activities of the KEAs: fostering solidarity and "throwing sand in the wheels". Fostering solidarity is a form of self-formation that challenges and subverts the subjectivity imposed by the government of unemployment. It forms the self as empowered and in solidarity with others, opposed to the individualized victimized Hartz IV subjectivity. Thereby, it enables and encourages different forms of individual resistance based on personal experience of oppression. Individual resistance can be cooperative when the individual claims its rights with the job centre or agonal when the basic values and power relations entailed in Hartz IV are challenged. Individual forms of resistance are generally tactical and based on the individual experience rather than higher goals and objectives. Therefore, different views, experiences and types of resistance can be incorporated and enabled within one organization. The KEAs do not prescribe but rather enable individual resistance against the government of unemployment. However, they encourage agonal forms of resistance or "throwing sand in the wheels". Through individual acts of disobedience or legal disputes, individuals can contribute to the disruption and subversion of the mechanisms of the government of unemployment. Furthermore, on the collective level, the KEAs engage in subversive militant protest. The small group and the individual connections, through which it establishes its networks, allow the KEAs to engage in unpredictable militant activities, effective by disturbing the smooth functioning of the government of unemployment.

The strength of the KEAs is their grassroots structure and emphasis of individual connections based on personal experience. Therefore, the growth of this movement should not consist in the growth of the group or their activities. Rather, it is necessary to encourage individuals to become politically active and form similar groups in other localities. Self-organization allows the particular needs and experiences of personally affected individuals to be articulated and transformed into collective action. Therefore, other groups will not necessarily resemble the KEAs in their make-up and activities. However, significant elements worth applying to other localities is the informal grassroots structure and the empowerment of individuals to resist in their own way based on their own experience. Furthermore, building solidarity is necessary to replace the loss of social and political rights of the unemployed and enable the poor, working or nonworking and across national boundaries to become politically active and challenge oppressive power structures embodied in the government of unemployment. 


\section{REFERENCES}

Blaschke, Ronald. 2003. "Arm, arbeitslos und aktiv: Bürgerschaftliches und politisches Engagement armer und arbeitsloser Bürger in eigener Sache". In Sozial Benachteiligte engagieren sich doch. Über lokales Engagement und soziale Ausgrenzung und die Schwierigkeiten der Gemeinwesenarbeit, edited by Chantal Munsch. Weinheim and Munich: JuventaVerlag.

Butterwegge, Christoph. 2010. "Sozialstaat im Wandel". Justiz 104: 368.

Cole, Matthew. 2007. "From employment exchange to Jobcentre Plus: the changing institutional context of unemployment". History of the human sciences 20: 129-146.

Dean, Mitchell. 1995. "Governing the unemployed self in an active society". Economy and Society 24: 559-583.

Duarte, André. 2007. “Hannah Arendt, Biopolitics and the problem of violence: from animal laborans to homo sacer". In Hannah Arendt and the uses of history: imperialism, nation, race and genocide, edited by Richard H. King and Dan Stone, 21-37. London: Berghahn Books.

Foucault, Michel. 1980. Power/Knowledge: Selected Interviews and other Writings 1972-1977. Edited by Colin Gordon. New York: Pantheon.

Foucault, Michel. 1991. "Governmentality". In The Foucault Effect: Studies in Governmentality, edited by Graham Burchell, Colin Gordon and Peter Miller. Hempel Hempstead and Chicago: Harvest Wheatsheaf and University of Chicago Press.

Heiter, Bernd. 2008. '“' ... nicht dermaßen regiert zu warden". Über juridische Formen, Hartz IV und Widerstandspraktiken". In Widerstand Denken: Michel Foucault und die Grenzen der Macht, edited by Daniel Hechler and Axel Phillips. Bielefeld: transcript Verlag.

Howe, Leo. 1998. "Scrounger, Worker, Beggarman, Cheat: The Dynamics of Unemployment and the Politics of Resistance in Belfast". The Journal of the Royal Anthropological Institute 4: 531550.

Ingram, Helen M. and Schneider, Anne L. 2005. "Introduction: Public Policy and the Social Construction of Deservedness". In Deserving and Entitled: Social Constructions and Public Policy, edited by Helen M. Ingram and Anne L. Schneider. Albany: State University of New York Press.

Lahusen, Christian. 2012. "The Protests of the Unemployed in France, Germany and Sweden(19942004): Protest Dynamics and Political Contexts". Social Movement Studies: Journal of Social, Cultural and Political Protest. Accessed September 25, 2012. DOI:

10.1080/14742837.2012.723369.

This work is licensed under a Creative Commons AttributionNonCommercialNoDerivs 3.0 Unported License. 
Mcdonald, Catherine and Marston, Greg. 2005. "Workfare as welfare: governing unemployment in the advanced liberal state". Critical Social Policy 25: 374. DOI: 10.1177/0261018305054077.

Philipps, Axel. 2008. “Proteste und Resistenzen der Erwerbslosen”. In Widerstand Denken: Michel Foucault und die Grenzen der Macht, edited by Daniel Hechler and Axel Phillips. Bielefeld: transcript Verlag.

Pickett, Brent L. 1996. "Foucault and the Politics of Resistance”. Polity 28: 445-466. Accessed October 3, 2012.

Rein, Harald. 1997. "„Wir kämpfen um das, was wir brauchen“: Stand und Perspektiven des Erwerbslosenprotests". Forschungsjournal NSB 10: 70-75.

Rose, Nicholas. 2010. "Political power beyond the state: problematics of government". The British journal of sociology 61: 173-205.

Roth, Karl Heinz. 2010. “Die globale Krise: Bisheriger Verlauf Entwicklungstendenzen Wahrnehmungen und Handlungsmöglichkeiten von unten". Sozial.Geschichte Online 2: 124-163.

Spilker, Niels. 2010. "Zur Rationalität der lebenslang lernenden Ich AG." MOMENTUM 10 Track 3" Arbeitsrecht und Arbeitsverhältnisse", 21.-24.10.2010. Hallstadt, Österreich.

Thompson, Kevin. 2003. "Forms of resistance: Foucault on tactical reversal and self-formation". Continental Philosophy Review 36: 113-138.

Trube, Achim. 2004. "Bürgerschaftliches Engagement gegen die Folgen der Arbeitslosigkeit Chancen und Handlungsmöglichkeiten". Betrifft: Bürgergesellschaft 02.

Valverde, Mariana. 1996. "'Despotism'and ethical liberal governance". Economy and Society 25: 357372.

Voigtländer, Leiv Eirik. 2012. “Erwerbsloseninitiativen, aktivierende Arbeitsmarktpolitik und Engagementpolitik. Von den Schwierigkeiten, an der eigenen sozialpolitischen Zurichtung nicht zu partizipieren”. In Promotionskolleg „Demokratie und Kapitalismus“ : Perspektiven der Demokratie. Gesellschaftspolitische Interventionsmöglichkeiten im Spannungsverhältnis zwischen Demokratisierung und kapitalistischen Strukturen, Tagungsband, Siegen, edited by Kyrosch Alidusti. 111-121. 